Gunaratnam Y, Oliviere D, eds. Narrative and Stories in Health care: Illness, Dying, and Bereavement. Oxford: Oxford University Press, 2009:162-75.

45. Gabriel Y. The Voice of Experience and the Voice of the Expert - can they Speak to Each Other? In:
Hurwitz B, Greenhalgh T, Skultans V, eds. Narrative Research in Health and IIIness. Oxford: BMJ Books, Blackwell Publishing, 2004:168-85.

46. Charon R. In: Vanetta J, Schleifer R, Crow S, eds Medicine and Humanistic Understanding: the
Significance of Literature in Medical Practice. Philadelphia, PA: University of Pennsylvania Press, 2004.

47. Frank AW. Asking the right question about pain: narrative and phronesis. Lit Med 2004;23:209-25.

\title{
Poem
}

\section{The Lady in Pink}

From the cancer patient to the surgeon

By Rachel Brown

There was a young lady who said

As she lay-quite exposed-in a bed

"When poking around

I think that I've found

A lump that has filled me with dread"

So they kneaded and massaged and squeezed

And sampled a smidgeon to freeze

And he told her quite straight

That her cancer was late

But he'd cut it all out-if she pleased.

Then she said to the surgical team

"I think that your plans are extreme

Though you may be the best

You are only the guest

Of boobs owned and grown by a queen."

But when he had done what they do

She found that her outlook was new

When her breast disappeared

Her foot reappeared

She'd a vertical view of her shoe

And she thought - now he'd done with his knife-

She was going to get on with her life

She said to herself,

"I am not on the shelf

And my girls have always looked nice"

Then said the young lady in pink,

"The results of mastectomy stink

Though my tits are pits

I just love them to bits

Can you give them a tweak, do you think?"

For Alison and Martha, and all those women who face cancer with courage and style.

\section{Rachel Margaret Anne Brown}

Correspondence to Rachel Margaret Anne Brown, University of Missouri School of Medicine, MA215 Medical Sciences Building, Columbia, M0 65212, USA; brownrac@health.missouri.edu

Competing interests None.

Provenance and peer review Not commissioned; not externally peer reviewed.

Published Online First 8 June 2011

Med Humanit 2011;37:72. doi:10.1136/jmh.2011.007054 